the status of Fort Brown from that of the most unhealthy to one of the most healthy garrisons in the Army has been accomplished solely by the use of a pure water for drinking and cooking, an accidental consequence of the introduction and use of an ice machine. Formerly the water supply was pumped from the river into settling tanks and distributed for use. It is so pumped and distributed now for general purposes; but the water for cooking and drinking is obtained from a steam condensing coil connected with the ice machine. Distilled water was introduced in 1890 and the extraordinary change in the health of the garrison can be attributed to nothing else than to its use; for all the other sanitary conditions and surroundings of the post remain as they were during the years of insalubrity and high rates."

Fort Ringgold, Texas, gives corroborative testimony to the foregoing. Here distilled water was introduced in 1886. The post surgeon considers that its use has reduced the sick rate one-balf since that time, and that most of his admissions for malarial disease are among troops whose duties have taken them away temporarily from the post. As a matter of published record the admissions at this station have fallen from 2,304 per thousand of strength during the calendar year 1885 to such rates as 562 in 1889,865 in 1890 and 1,366 during the past year. Respectfully yours,

Charles Smart, Major and Surgeon, U.S. A.

\section{Morphinism in Children.}

Brooklyn, N. Y., Feb. 1, 1895.

To the Editor:-I am desirous of adding to the clinical literature of morphinism in children. If any reader of youp Journal has noted a case, and will furnish me details, I will appreciate the favor and give full credit.

$$
\text { J. B. MatTison, M.D. }
$$

\section{BOOK NOTICES.}

Clinical Gynecology, Modical and Surgical, for Students and Fractitioners. By eminent American teachers. Edited by John M. Krating, M.D., LL.D., and by Henry C. Coe, M.D., M.R.C.S. Illustrated. Cl., pp. 994. Philadelphia: J. B. Lippincott Company. 1895.

This volume contains articles by the late William Goodell, William H. Baker, Francis H. Davenport, Hunter Robb, Bache McE. Emmet, Barton C. Hirst, Matthew D. Mann, William M. Polk, J. Whitridge Williams, Henry T. Byford, Paul F. Munde, Herman J. Boldt, Henry C. Coe, William T. Lusk, Chauncey D. Palmer, Chas. Jewett, and John Polak, Edward E. Montgomery, Dudley P. Allen, Louis A. Duhring, and Milton B. Hartzell.

The surviving editor, Dr. Coe, states that owing to the untimely death of Dr. Keating, the completion of the work devolved upon the present editor, who has as far as possible carried out the plans and wishes of his lamented predecessor. While seeking to preserve that coherence which is desirable in a text-book, he has in the main allowed each contributor to consult his own judgment with regard to the arrangement and phraseology of his article, believing that in this way the individuality of each would best be preserved. The introduction is of unusual interest as the last printed words of the late Prof. Wm. Goodell, and he has assumed unconsciously the reminiscent and prophetic vein. We can give our readers no better idea of his style on this occasion than by quoting his own words:

"One advantage accruing to the writer of an introductory lies in the circumstance that he is not limited to any given text or narrowed down to a special topic. Untethered to thesis or theme, he can range at large over the whole field of the subject-matter and treat it pretty much as he pleases. Now as Mentor he can preach his homily; now as pupil he can con his hornbook.

"In this survey of gynecology I shall not hesitate to bor- row from my previous writings on the subject, without credit and without stint. I shall also use the pronoun of the first person, not from egotism, but in order to invest my own views with that personality which the editor has urged all his collaborators to assume. Nor, on occasions, shall I hesitate to show myself a proselyte of the gate-one who does not wholly yield up his creed to all the articles of orthodox medical belief, or subscribe to all the obligations of its ritual.

"With the ancients the Golden Age was in the past. With us it looms as the promise of the future; and indeed a great future lies before us. At the brink of the twentieth century let us look back upon the one that is fading away, and a truly wonderful one it has been."

And then the writer follows with a hasty but comprehensive review of the gynecology of the century now drawing to a close. We think him too sweeping when he asserts that the scientific treatment of appendicit is, of perityphlitis and of all intestinal and visceral lesions have come from the advances in gynecology. The truth is that modern abdominal surgery including gy necology proper, has come as a result of the immortal discoveries of Pasteur and the consequent technique of Lister. The writer of this remarkable introduction makes one of the most powerful appeals for the preservation of the ovaries, and as a citizen and patrio not less than a physician, he inveighs against the custom of the time by which the propagation of children has almost ceased to exist in our Anglo-Saxon stock, and he strongly urges conservatism in the use of the knife (see page 20) for ailments very frequently having their origin in the nervous system rather than in the reproductive organs.

"Nerve-strain," says our author, "or nerve-exhaustion comes largely from the frets, the griefs, the jealousies, the worries, the bustles, the carks and cares of life. Yet strangely enough, the most common symptoms of this form of nerve disorder in women are the very ones which lay tradition and dogmatic empiricism attribute to ailments of the womb." (Horace summed up these worries in the phrase, res anquste domui.)

The other chapters in the book are written from a clinical standpoint, and are the views of men of great experience as will be seen from the list above given. The work is systematic and we feel sure that it is as a whole the equal of any similar book, and in many respects it is immensely superior to an y gynecology recently issued. The surgery of the rectum and anus, and of the breast is given respectively by Dr. Montgomery and Dr. Allen.

Surgical Pathology and Therapentics. By John Collins WARREN, M.D., Professor of Surgery in Harvard University Surgeon to the Massachusetts General Hospital. Illustrated. Cl., pp. 832 . Philadelphia; W. B. Saunders. 1893 Price $\$ 6$.

Instead of dedicating this book to anybody, Professor Warren has the following motto from the Georgics of Virgil:

"Felix qui pofuit rerum cognoscere causus

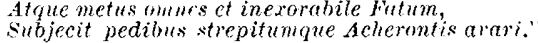

Which Dryden has freely translated:

"Happy the mall who studying Nature's laws

Through known effects can trace the secret cause,

His mind possessing in a quiet state

Fearless of wortune and resigned to Fate."

The book is divided into thirty-two chapters beside the appendix as follows: I, Bacteriology ; II, Surgical Bacteriology ; III, Hyperemia ; Iv, v, Simple Inflammation ; vi, vII, viI, Infective Inflammation; $I x$, The Process of Repair; $x$, Gangrene ; $x I$, Shock ; xII, Fever ; xIII, Surgical Fever ; xIV, Septicemia; xv, Pyemia ; xvI, Erysipelas; xvir, Hospital Gangrene; xvin, Tetanus; xIx, Hydrophobia ; xx, Actinomycosis ; xxI, Asthma; xxII, Glanders; xxII, Snakebite; xxIv, Tuberculosis; xxv, Surgical Tuberculosis of Joints; xxvi, Tuberculosis of the Soft Parts; xxvil, Diseases of Bone; xxvir. Tumors; xxr, Carcinoma; xxx, Sarcoma; xxxI, Benign Tumors; xxxIr, Aseptic and Antiseptic Surgery.

The appendix contains articles on the blood serum therapy in rabies; tetanus; treatment of cancer; methods of pre- 